\title{
Forskningsetiske utfordringer ved kvalitative studier
}

I vitenskapelige artikler finner man sjelden en inngående redegjørelse for forskningsetiske vurderinger.

\section{Forfattere}

Kristin Halvorsen

Førsteamanuensis

Institutt for sykepleie og helsefremmende arbeid, Oslomet - storbyuniversitetet

Heidi Jerpseth

Førsteamanuensis

Institutt for sykepleie og helsefremmende arbeid, Oslomet - storbyuniversitetet

Sykepleien Forskning 2019 14(57440)(e-57440)

DOI: https://doi.org/10.4220/Sykepleienf.2019.57440

Vanligvis gis det kun en kort konstatering om at studien er i tråd med gjeldende reguleringer og er godkjent av Regionale komiteer for medisinsk og helsefaglig forskningsetikk (REK) eller Norsk senter for forskningsdata (NSD). En godkjenning i REK eller NSD krever imidlertid en grundig redegjørelse for forskningsetiske aspekter ved studien. 
I det følgende presenteres det noen etiske betraktninger og utfordringer som aktualiseres i forskning, med et særlig blikk på kvalitativ forskning. Som bakteppe benyttes det erfaringer fra forfatternes ph.d.-arbeider, relevant litteratur og forskning samt publikasjoner fra De nasjonale forskningsetiske komiteene.

\section{Hensynet til forskningspersonene - det bærende elementet}

Det bærende elementet i forskningsetikk er hensynet til deltakerne og deres integritet. Et avgjørende prinsipp for å kunne ivareta respondentenes integritet er det frivillige informerte samtykket.

Men samtykke er ikke tilstrekkelig. Forskningen skal frembringe kunnskaper som enkeltpersoner eller grupper av personer har nytte av, og forskningen skal innebære ingen eller liten risiko for aktørene.

Respondentenes sårbarhet, eller sårbarhet hos personer som indirekte blir involvert i forskningen, har stor betydning for de forskningsetiske vurderingene (1-4).

\section{Reguleringer}

Historien har vist at hensynet til respondentene ikke er en selvfølge (1). Av den grunn finnes det flere reguleringer og forskningsetiske hensyn som ivaretar deltakere i gjennomføringen av medisinske og helsefaglige forskningsprosjekter.

Toneangivende innen helsefaglig forskning er Helsinkideklarasjonen, som de fleste andre lover og reguleringer bygger på (2). I Norge reguleres forskning innen medisin og helsefag av helseforskningsloven (3). Da denne loven kom i 2008, forenklet den prosedyrene for godkjenning av forskningsprosjekter. Heretter forholdt vi oss til «en lov, en postkasse.» 
En tommelfingerregel er at alle prosjekter som involverer sårbare grupper, skal godkjennes av REK. Et annet viktig poeng knyttet til om prosjekter skal godkjennes av REK eller kun meldes til NSD, er graden av helseopplysninger prosjektet inneholder.

I 2018 kom det en utvidet personvernlov knyttet til EUs GDPR (General Data Protection Regulations) (4, 5). Lovendringen er gjort for å styrke personvernet og har også stor innvirkning i forskningen. Her kan det være aktuelt å forespørre REK og/eller NSD ved tvil. Mye informasjon ligger også på hjemmesidene til REK (6) og NSD (7).

På REKs hjemmesider finnes det også lenker til skjemaer for forespørsel om prosjekter er meldepliktige eller ikke. Prosjekter som kun meldes til NSD, kan være for eksempel prosjekter som ikke inneholder helseopplysninger, eller som involverer samtykkekompetente tidligere pasienter, pårørende og foreldre, eller kun helsepersonell.

\section{Kvalitativ forskning}

«Kvalitative metoder bygger på teorier om fortolkning og menneskelige erfaringer» (3, s. 7). I forfatternes doktorgradsarbeider $(8,9)$ var vi begge opptatt av å få frem dybdekunnskap om erfaringer knyttet til vanskelige handlinger og valg.

Jerpseth (8) undersøkte hvordan intensivleger og lungeleger, lungesykepleiere og intensivsykepleiere samt pasienter vurderte pasientens medbestemmelse i vanskelige valg knyttet til respiratorbehandling eller annen avansert pustehjelp i langtkommende stadier av kols.

Halvorsen (9) utforsket hvilke handlinger og valg intensivleger og intensivsykepleiere sto overfor $\mathrm{i}$ vanskelige prioriteringsspørsmål om å begrense intensivbehandling. Ut fra forskningsspørsmålene var kvalitativ metode best egnet til å søke svar. 
I Jerpseths studie ble det benyttet

fokusgruppeintervjuer av helsepersonell og

dybdeintervjuer av pasienter. Halvorsen benyttet

deltakende observasjon av helsepersonell i

intensivavdeling og dybdeintervjuer av

intensivsykepleiere og intensivleger.

I kjølvannet av metodevalg og

datainnsamlingsstrategier fulgte det flere

forskningsetiske vurderinger og utfordringer. Noen av

disse vil vi belyse her.

\section{Utfordringer ved samtykke i kvalitativ forskning}

I Halvorsens ph.d.-arbeid var deltakende observasjon av helsepersonell i intensivavdeling en utfordring. Under observasjonen fikk hun tilgang til opplysninger om sårbare, ikke samtykkekompetente pasienter, til tross for at fokuset var helsepersonell som ga frivillig og skriftlig informert samtykke.

En måte å løse slike dilemmaer på er å innhente samtykke fra pårørende, som da på vegne av den syke enten kan nekte eller akseptere å delta. Dette ble alternativet i studien, i tillegg til unntak fra taushetsplikten, i og med at hun gjennom deltakende observasjon potensielt ville få kjennskap til taushetsbelagt informasjon.

Det er viktig å merke seg at forskere er underlagt taushetsplikt, og i Halvorsens studie ble det undertegnet taushetserklæring i de aktuelle intensivavdelingene.

Det er svært strenge krav til deltakende observasjon av sårbare grupper. Hem og medarbeidere (10) argumenter for at det i enkelte tilfeller kan bli så vanskelig å slippe til i et forskningsfelt, og at verdifull forskning - med liten risiko for pasienten, men med stor betydning for gruppen av pasienter og samfunnet for øvrig - kan gå tapt. 
Det hender at REK vurderer ulikt i saker som omhandler observasjon av helsepersonell i kliniske avdelinger, der det vil være mulig å få kjennskap til taushetsbelagt informasjon om pasienter. På samme tid som Halvorsen gjennomførte sitt ph.d.-prosjekt, var det en annen studie som benyttet deltakende observasjon av helsepersonell i intensivavdeling, der det også var mulig å få kjennskap til taushetsbelagt informasjon.

Denne studien falt utenfor REKs mandat (11). Dette er et av flere liknende eksempler. Slike situasjoner kan gjøre det vanskelig for forskere å vurdere om studien skal godkjennes av REK eller ikke. I saker som dette kan REK se forhold som forskeren ikke ser, noe som understreker betydningen av å benytte de elektroniske forhåndsvurderingene som REK tilbyr (6).

\section{$\equiv$ «Deltakere i forskning skal alltid kunne trekke seg fra studien på en enkel måte.»}

En annen utfordring ved samtykke innenfor kvalitativ forskning er at forskningsspørsmålene gjerne er mer fleksible, noe som innebærer at andre og nye temaer kan fremkomme enn de spørsmålene som var der i utgangspunktet. Det kan skape utfordringer i henhold til samtykket, fordi studien kan endre seg.

En måte å møte denne utfordringen på, er å la respondenten få lese utskrift av sitt eget intervju for godkjenning, eventuelt å korrigere eller slette utsagn som vedkommende ikke ønsker å ha med. Om dette er hensiktsmessig, må forskeren vurdere opp mot andre hensyn, men forskeren kan ikke nekte deltakere i studier innsyn i materialet som omhandler dem selv. Innsyn er en rettighet vedkommende har ifølge ny lov om personvern (7) 
En annen måte å møte utfordringen med endringer i studien på er gjennom eventuelt å gjenta samtykke. Det vil si at respondentene samtykker på nytt hvis de dataene som har fremkommet, har ført til betydelige endringer som ligger utover det respondenten er informert om og har samtykket til i utgangspunktet $(12,13)$.

Deltakere i forskning skal alltid kunne trekke seg fra studien på en enkel måte. De skal være godt informert om studien og om sine rettigheter, hvordan de kan trekke seg fra studien, få innsyn i materialet samt hvilken risiko, nytte og eventuelle ulemper studien vil ha for dem. De må også få informasjon om at data som allerede er inngått i analysen, ikke kan trekkes fra studien $(1,2,6,7)$.

\section{Anonymitet, avidentifisering og konfidensialitet}

Anonymisering kan by på forskningsetiske utfordringer i kvalitativ forskning. Utvalgene er ofte relativt små, noe som kan true anonymiteten og gjøre deltakerne mer sårbare med hensyn til gjenkjenning.

Det er svært viktig at alt datamaterialet skrives ut avidentifisert, det vil si uten navn, stedsgjengivelse eller forhold som kan bidra til gjenkjennelse, slik at respondentene ikke kan identifiseres. I formidling av funn og bruk av sitater er det viktig ikke å benytte gjenkjennelige språklige formuleringer. Her må man være oppmerksom på for eksempel bruk av dialekter og/eller personlige måter å utrykke seg på.

På den annen side må man som forsker være svært oppmerksom på at meningsinnholdet i sitater bevares. Her kan det være en vanskelig avveining. Halvorsen erfarte det i sitt prosjekt da hun intervjuet respondenter med en dialekt som på en helt egen måte fikk frem mening i sitatene, men av hensyn til gjenkjennelse måtte teksten skrives uten dialektuttrykkene. 
Malterud (9) fremhever nødvendigheten av å bevare respekten for deltakere i forskningen i presentasjon og formidling av resultater. Forskeren skal være varsom med å bruke sitater som kan latterliggjøre eller være sårende.

Et annet aspekt er at et stort materiale være utfordrende med hensyn til å få frem materialets kompleksitet. Det kan være vanskelig å velge sitater som representerer alle nyansene i materialet. Sitater skal være troverdige, vise respekt for informanten og formidle mangfoldigheten i resultatene på en sannferdig måte $(12,13)$.

Vi som har skrevet denne artikkelen, opplevde begge hvor komplisert det kan være å få frem mangfoldigheten i et stort materiale. En viktig validering for å få frem materialets nyanser, er å være flere forskere i analyseprosessen.

\section{Relasjon og tillit}

Dybdeintervjuer, fokusgruppeintervjuer og deltakende observasjon innebærer på ulike måter at forskningsdeltakerne og forskeren er i en relasjon som må være preget av tillit. Uten tillit vil det være vanskelig, for ikke å si umulig, å få gode data. Det å bruke tid til å skape tillit og forvalte tilliten på en respektfull måte står i en særskilt posisjon i kvalitativ forskning $(1,8,9,12,13)$.

I dybdeintervjuer deler forskningsdeltakere erfaringer som kan være en kombinasjon av såre, vanskelige og gode opplevelser. I intervjuene fra intensivavdelingen om vanskelige prioriteringsvalg begynte forskningspersoner ved flere anledninger å gråte.

Det var komplekse og emosjonelle temaer å snakke om, og beslutninger der de hadde hatt stor tvil og stått i mye lidelse - beslutninger der konklusjonene ikke «fantes i en glasskule», men gjennom mange avveininger av rett og galt (9). 


\section{三 «Uten tillit vil det være vanskelig, for ikke å si umulig, å få gode data.»}

\section{Jerpseths studie intervjuet hun pasienter med}

langtkommen kols, der flere fortalte om sine tanker om døden (8). Det var vanskelig både å stille spørsmålene og lytte til svarene på en respektfull og tillitsfull måte.

Deltakerne viste forskeren stor tillit og slapp henne inn i et rom det også var vanskelig for dem å være i. I fokusgruppeintervjuene derimot snakket flere om pasientgruppen med varierende grad av respekt. Dette var også vanskelig å møte, når lidelsen til pasientene var så tydelig (8).

Det finnes ingen oppskrift på hvordan slike situasjoner skal møtes, men vi vil understreke at det å være godt forberedt, åpen, lyttende og spørrende i møte med forskningsdeltakerne er gode verktøy. Det må vises respekt for det såre og vanskelige, der også det man «ikke liker å høre», får plass.

I deltakende observasjon er tillit helt nødvendig for gode og troverdige observasjoner. Tid til å bygge relasjoner er et viktig virkemiddel. De som blir observert, må stole på deg som forsker, de må vite at du vil dem vel, samtidig som du som forsker også skal formidle troverdig $(9,10,12)$.

I Halvorsens ph.d.-arbeid ble det brukt god tid og mange pilotobservasjoner før selve datainnsamlingen startet, nettopp for å skape tillit og troverdighet (9).

\section{Asymmetri i maktforhold}


I kvalitativ forskning skal man også være oppmerksom på asymmetrien i maktforholdet som kan oppstå mellom forskeren og forskningsdeltakerne, og også på maktubalansen mellom deltakere i for eksempel fokusgruppeintervjuer. Opplevd maktasymmetri kan påvirke hva som kommer frem av data, og det kan i verste fall bidra til vonde erfaringer for deltakerne som er involvert $(8-10,12)$.

Begge forfatterne av denne kronikken erfarte hvordan vi måtte vurdere maktforholdet i planlegging og gjennomføring av intervjuer. Asymmetriske maktforhold mellom profesjoner var en utfordring som Jerpseth måtte vurdere i planleggingen av fokusgruppeintervjuene. I samme pilotintervju deltok både leger og sykepleiere.

I dette intervjuet ble sykepleierne veldig stille. Det ble forstått som at det var en maktskjevhet som gjorde det vanskeligere for sykepleierne å diskutere åpent i fokusgruppen. På bakgrunn av dette ble det besluttet å gjøre intervjuer med henholdsvis bare leger og bare sykepleiere i fokusgruppene (8).

\section{Forsker, ikke terapeut}

Flere forfattere innen kvalitativ metode $(1,9,10)$ belyser balansen mellom å være forsker og å være terapeut. Det kan være nødvendig å avklare denne rollen overfor respondentene. Det kan oppstå situasjoner der forskeren og respondent snakker om fortrolige og vanskelige temaer, der forskeren må gjøre det klart at hun eller han ikke er terapeut.

Deltakere i forskning kan i mange tilfeller dele mye fortrolig informasjon, og forskeren må være svært oppmerksom i dette landskapet som omhandler nærhet og distanse og respondentens integritet (1). 
I enkelte intervjusituasjoner kan det komme opp

forhold som gjør at forskeren blir bekymret for respondentens psykiske eller fysiske helse. I slike situasjoner kan man be vedkommende ta kontakt med fastlegen, hjemmesykepleien eller annet. I helt spesielle situasjoner kan forskeren måtte kontakte relevant helsepersonell.

Jerpseth intervjuet svært skrøpelige personer med kols som bodde hjemme. Her hadde Jerpseth en avtale om å kontakte lungesykepleieren ved poliklinikken som rekrutterte, hvis hun var bekymret for forskningspersonens helsesituasjon. Ved en anledning måtte hun benytte seg av denne avtalen (8).

\section{Oppbevaring av forskningsdata}

Alle forskere er pliktige til å oppbevare forskningsdata trygt og sikkert, slik at anonymitet, konfidensialitet og integritet overholdes ut fra de gjeldende lover og regler og godkjenninger gitt til studien. Kvalitativ forskning inneholder ofte store tekstutskrifter. Disse må oppbevares forsvarlig innelåst og utilgjengelig for andre enn de som skal ha tilgang til dem.

Som nevnt er det i den senere tiden kommet en ny personvernlov og nye retningslinjer for oppbevaring av forskningsdata og risikovurderinger knyttet til forskningsmateriale gjennom EUs GDPR-direktiv (47). Forskere må sette seg inn i direktivet og egne institusjoners retningslinjer knyttet til dette.

\section{Brukermedvirkning}

I de senere årene har brukermedvirkning fått mye større plass i forskningen. Brukermedvirkning i kvalitativ forskning bidrar til en god måte å skape tillitsfulle relasjoner på og få en god maktbalanse, der forskningsdeltakerne er med på å bestemme for eksempel hvordan en fokusgruppe skal settes sammen. 
Det kan bidra til at det stilles mer relevante spørsmål og/eller at funn får andre nyanser ved at de også blir tolket gjennom brukerens blikk. Brukermedvirkning kan styrke forskningsetikken og kvaliteten i en aktuell studie.

\section{Avslutning}

Denne kronikken er ikke en uttømmende gjennomgang av forskningsetiske hensyn innenfor kvalitativ metode, men peker på noen forhold til ettertanke og refleksjon.

Forskningsetiske hensyn må være en kontinuerlig vurdering gjennom hele forskningsprosessen i all forskning, slik at deltakerne i forskning ivaretas best mulig, og at forskningen bidrar til ny og verdifull innsikt og kunnskap for person, gruppe og samfunn.

Hvordan vi valgte å møte de utfordringene vi støtte på, kan utforskes videre i våre ph.d.-avhandlinger $(8,9)$.

\section{Referanser}

1. Ruter KW, Førde R, Solbakk JH. Medisinsk og helsefaglig etikk. 2. utg. Oslo: Gyldendal Akademisk; 2007.

2. Helsinkideklarasjonen 1964/2008.

Tilgjengelig fra: https://www.etikkom.no/FBIB/Praktisk/Lover-ogretningslinjer/Helsinkideklarasjonen/ (nedlastet 30.08.2018).

3. Lov 20. juni $2008 \mathrm{nr} .44$ om medisinsk og helsefaglig forskning (helseforskningsloven).

Tilgjengelig fra:

https://lovdata.no/dokument/NL/lov/2008-06-20-44 (nedlastet 31.08.2018). 
4. Lov 15. juni $2018 \mathrm{nr} .38$ om behandling av personvernopplysninger (personopplysningsloven). Tilgjengelig fra:

https://lovdata.no/dokument/NL/lov/2018-06-15-38 (nedlastet 16.09.2019).

5. Datatilsynet. Lover og regler. Tilgjengelig fra: https://www.datatilsynet.no/regelverk-ogverktoy/lover-og-regler/ (nedlastet 16.09.2019).

6. Den nasjonale forskningsetiske komité for medisin og helsefag (NEM). Veiledning for forskningsetisk og vitenskapelig vurdering av kvalitative forskningsprosjekt innen medisin og helsefag. Oslo: De nasjonale forskningsetiske komiteene; 2009. Tilgjengelig fra: https://www.etikkom.no/forskningsetiskeretningslinjer/Medisin-og-helse/Kvalitativ-forskning/ (nedlastet 06.08.2019).

7. Norsk senter for forskningsdata.

Personverntjenester. Tilgjengelig fra:

https://nsd.no/personvernombud/ (nedlastet 16.09.2019).

8. Jerpseth H. Older patients with late-stage

COPD: care and clinical decision-making. A qualitative study with perspectives of patients, nurses and physicians. (Doktoravhandling.) Oslo:

Universitetet i Oslo, Det medisinske fakultet; 2017.

Tilgjengelig fra:

https://www.duo.uio.no/handle/10852/55713 (nedlastet 06.08.2019).

9. Halvorsen $\mathrm{K}$. The ethics of bedside priorities in intensive care. Value choices and considerations. A qualitative study. (Doktoravhandling.) Oslo:

Universitetet i Oslo, Det medisinske fakultet; 2009.

Tilgjengelig fra:

https://www.duo.uio.no/handle/10852/59086 (nedlastet 06.08.2019). 
10. Hem M, Heggen K, Ruyter KW.

Questionable requirement for consent in observational

research in psychiatry. Nursing Ethics. 2007;14:41-53.

11. Olsvold N. Ansvar og yrkesrolle. Om den sosiale organiseringen av ansvar i sykehus.

(Doktoravhandling.) Oslo: Universitetet i Oslo, Det medisinske fakultet; 2011.

12. Malterud K. Kvalitative forskningsmetoder for medisin og helsefag. 4. utg. Oslo:

Universitetsforlaget; 2017.

13. Kvale S, Brinkmann S. Det kvalitative forskningsintervju. 2. utg. Oslo: Gyldendal Akademisk; 2010. 